\title{
ANALISIS KEBUTUHAN LKPD UNTUK MENINGKATKAN HASIL BELAJAR SISWA PADA MATERI SEL DI SMA NEGERI 8 PALEMBANG
}

\author{
Lidya Husnita ${ }^{1}$ \\ Meli Astriani ${ }^{2}$ \\ Saleh Hidayat ${ }^{3}$ \\ Sri Wardhani ${ }^{4}$ \\ 1,2,3,4) Program Studi Pendidikan Biologi, Program Pascasarjana, Universitas \\ Muhammadiyah Palembang \\ E-mail: meliastriani.g201@gmail.com
}

\begin{abstract}
Abstrack: This needs analysis aims to determine what teaching materials are needed by teachers on cell material at SMA Negeri 8 Palembang. The population of distributing questionnaires in SMA Negeri 8 Palembang, the sample of the distribution of class XI IPA 7 was 30 students. The instrument used was the teacher's questionnaire sheet totaling 18 questions, 13 student questionnaire sheets complete with lattices from the teacher questionnaire sheets, and student questionnaire sheets on cell material and documentation. Analysis of the needs of the teacher and student questionnaire questions using language validation experts at $83.07 \%$. From the results of the needs analysis at SMA Negeri 8 Palembang in class XI IPA 7 that teachers need teaching materials in the form of Student Worksheets because the teacher has never made an Student Worksheets. The cell material at SMA Negeri 8 Palembang was difficult for students to understand regarding cell organelles, cell functions, and cell differences. The Problem Based Learning Model turns out that the teacher has not used this model in online learning, the teacher only gives assignments to students through the WhatApps group, Google Classroom and does not use Zoom Meeting, so that students do not understand and understand cell material and student learning outcomes still have not reached KKM (Minimum completeness criteria).
\end{abstract}

Kata kunci: Learning outcomes, Student Worksheets, Cell material, Problem Based Learning

\section{PENDAHULUAN}

LKPD (Lembar Kerja Peserta Didik) sendiri adalah sekumpulan kegiatan yang mendasar yang harus dilakukan oleh peserta didik dalam untuk memaksimalkan terhadap pemahaman untuk upaya pembentukan kemampuan dasar yang sesuai dengan indikator. LKPD ini digunakan dalam kegiatan proses pembelajaran yang seharusnya sesuai dengan adanya tuntutan Kompetensi Dasar (KD), memotivasi peserta didiknya serta dapat menarik minat dan perhatian kepada peserta didik untuk belajar. (Syabani dkk, 2018).

LKPD yang digunakan harus LKPD yang siap pakai serta berisi berupa materi-materi pembelajaran dan soal-soal. Sumber belajar itu tidak fokus kepada buku saja melainkan juga bisa dari koran, cerpen, orang, internet serta dari lingkungan, sehingga pengetahuan peserta didik tersebut tidak hanya terbatas oleh buku saja. LKPD ini dapat memancing peserta didik untuk terlibat aktif pada materi yang di bahas, LKPD juga dapat membuat dalam proses pembelajaran lebih aktif.

Sebagai media pembelajaran,
LKPD mempunyai beberapa
komponen atau unsur yang menjadikannya layak digunakan sebagai media pembelajaran, hal ini dipertegas oleh Wulandari (2013) yang mengatakan bahwa peran LKPD sangat penting dalam pelaksanaan 
proses pembelajaran karena mampu meningkatkan aktivitas peserta didik dalam proses pembelajaran.

Unsur-unsur LKPD menurut Sari (2011) diantaranya judul, petunjuk belajar, indikator pembelajaran, informasi pendukung, langkah kerja, dan penilaian. Hal ini juga dipertegas dengan lebih rinci oleh Widyantini (2013) yang menyebutkan unsur unsur LKPD yaitu judul, mata pelajaran, semester, tempat, petunjuk belajar, kompetensi yang akan dicapai, indikator pembelajaran, informasi pendukung, alat dan bahan dalam mengerjakan LKPD, langkah kerja, dan penilaian. Selain LKPD yang akan dikembangkan tentu diperlukan perangkat penunjang lainnya.

Dalam penelitian ini peneliti menggunakan model pembelajaran PBL (Problem Based Learning), Menurut (Ibrhim, 2013) adalah penilaian kegiatan pembelajaran dapat diambil melalui pengamatan, lalu kemampuan peserta didik dalam merumuskan pertanyaan, serta upaya peserta didik dalam menciptakan solusi untuk memecahkan permasalahan. Menurut Ethetington, M. B (Craig, 2015) model PBL (Problem Based Learning) merupakan sebuah metode yang berpusat pada peserta didik dengan melibatkan dalam cara belajar melalui pemecahan masalah.

Model PBL (Problem Based Learning) adalah pembelajaran yang berdasarkan pada teori kognitif termasuk didalamnya belajar konstruktivisme. Langkah-langkah melaksanakan PBL ada 5 fase, yaitu : 1) mengorientasi siswa pada masalah, 2) mengorganisasi siswa untuk meneliti, 3) membantu investigasi mandiri dan berkelompok, mengembangkan dan menyajikan hasil karya, 5) menganalisis proses pemecahan masalah (Arends, 2008).
Hasil belajar merupakan suatu penialain akhir pada proses serta pengenalan yang telah dilakukan berulang-ulang serta tersimpan dalam waktu lama, karena hasil belajar ini turut dalam membentuk pribadi individu yang selalu ingin mencapai hasil yang lebih baik, sehingga nantnya akan mengubah cara berpikir dan menghasilkan perilaku yang lebih baik (Sulastri dkk, 2014).

Berdasarkan hasil pengisian angket yang telah dilakukan dengan guru biologi di SMA Negeri 8 Palembang ini mengenai materi sel di kelas XI semester ganjil. Permasalahan pada materi tersebut bahwa materi sel ini sulit karena untuk dipahami oleh siswa-siswa mulai dari organel-organel sel, fungsi-fungsi sel serta perbedaan sel. Contohnya pada organel sel hewan dan sel tumbuhan, misalnya pada organel mitokondria, lisosom.

Berdasarkan hasil pengisian angket kepada guru terkait dengan model pembelajaran bahwa model PBL (Problem Based Learning) belum diterapkan dalam pembelajaran daring. Hal tersebut dikarenakan guru pada proses pembelajaran daring hanya memberikan tugas kepada siswa melalui media social seperti grup WhatApps dan Google Classroom. Selain itu juga, guru tidak menggunakan platform zoom selama pembelajaran daring.

Implementasi pembelajaran daring yang dilakukan guru juga belum menggunakan bahan ajar. Hasil observasi di lapangan memperlihatkan bahwa bahan ajar yang digunakan guru bukan buatan sendiri dan masih umum. Terbatasnya bahan ajar yang memberdayakan keterampilan peserta juga masih rendah dan bahan ajar belum terintegrasi dengan langkahlangkah model pembelajaran. Berdasarkan uraian tersebut maka perlu untuk dilakukan analisis kebutuhan guru terhadap bahan ajar LKPD 
berbasis model PBL untuk meningkatkan hasil belajar siswa di SMA Negeri 8 Palembang.

\section{METODE}

Pengumpulan data dengan mengunakan Wawancara dan angket. Kisi-kisi lembar angket untuk guru meliputi 4 komponen, yaitu; Bahan ajar memiliki 2 indikator pada butir angket no. 1,2,3,4,5, Model pembelajaran memiliki 3 indikator pada butir angket no. $6,7,8,9,10$, Hasil belajar memiliki 1 indokator pada butir angket no. 11,12,13 dan Materi sel memiliki 1 indikator pada butir angekt no. $14,15,16,17,18$.

Kisi-kisi lembar angket untuk siswa meliputi 4 komponen, yaitu; Bahan ajar memiliki 2 indikator pada butir angket no.1 dan 2, Model pembelajaran memiliki 2 indikator pada butir angket no. 3 dan 4, Hasil belajar 1 indikator butir angket no. 5 dan Materi sel 3 indikator pada butir angket no. $6,7,8,9,10,11,12,13$.

\section{Data Validasi Instrument Analisis Kebutuhan}

$$
\begin{aligned}
& \begin{array}{c}
\text { Skor akhir uji validasi konstruk } \\
\text { nilai skala jawaban }
\end{array} \\
& =\frac{5(1)+4(12)+3(0)+2(0)+1(0)}{(5 \times 13)} \times 100 \\
& =\frac{(10)+(44)+(0)+(0)+(0)}{65} \times 100 \\
& =\frac{5400}{65}=83,07 \% \text { (sangat valid, dapat } \\
& \text { digunakan tanpa revisi). }
\end{aligned}
$$

\section{HASIL}

Berdasarkan hasil analisis kebutuhan lembar angket guru diperoleh data bahwa sebelumnya guru menggunakan bahan ajar pada saat pembelajaran daring berupa modul dan media. Guru juga menyampaikan pembelajaran selama daring tidak menerapkan model pembelajaran bahkan tidak mengetahui sintaks dari model pembelajaran. Analisis terhadap materi kelas XI juga ditemukan bahwa guru menyatakan sulit dalam mengajarkan materi sel. Beberapa

\begin{tabular}{|c|c|c|}
\hline No. & Indikator & Jawaban \\
\hline 1 & $\begin{array}{l}\text { Bahan Ajar } \\
\text { yang digunakan } \\
\text { guru }\end{array}$ & $\begin{array}{l}\text { Modul dan } \\
\text { Media }\end{array}$ \\
\hline 2 & $\begin{array}{l}\text { Model } \\
\text { Pembelajaran }\end{array}$ & $\begin{array}{l}\text { Tidak } \\
\text { menggunakan } \\
\text { model } \\
\text { pembelajaran } \\
\text { selama daring }\end{array}$ \\
\hline 3 & $\begin{array}{l}\text { Materi sulit } \\
\text { kelas XI }\end{array}$ & $\begin{array}{l}\text { Sel dan } \\
\text { Peredaran } \\
\text { Darah }\end{array}$ \\
\hline 4 & Hasil Belajar & $\begin{array}{l}\text { Belum } \\
\text { mencapai } \\
\text { KKM }\end{array}$ \\
\hline 5 & $\begin{array}{l}\text { Setuju untuk } \\
\text { dibuatkan } \\
\text { LKPD berbasis } \\
\text { model PBL } \\
\text { pada materi sel }\end{array}$ & $\mathrm{Ya}$ \\
\hline
\end{tabular}
indikator analisis kebutuhan terhadap guru dapat dilihat pada Tabel 1.

Tabel 1. Hasil Analisis Angket Guru

Analisis kebutuhan angket juga disebar kepada siswa untuk mengetahui bahan ajar yang pernah digunakan siswa pada mata pelajaran biologi materi sel. Data hasil angket dapat dilihat pada Gambar 1 dan 2.

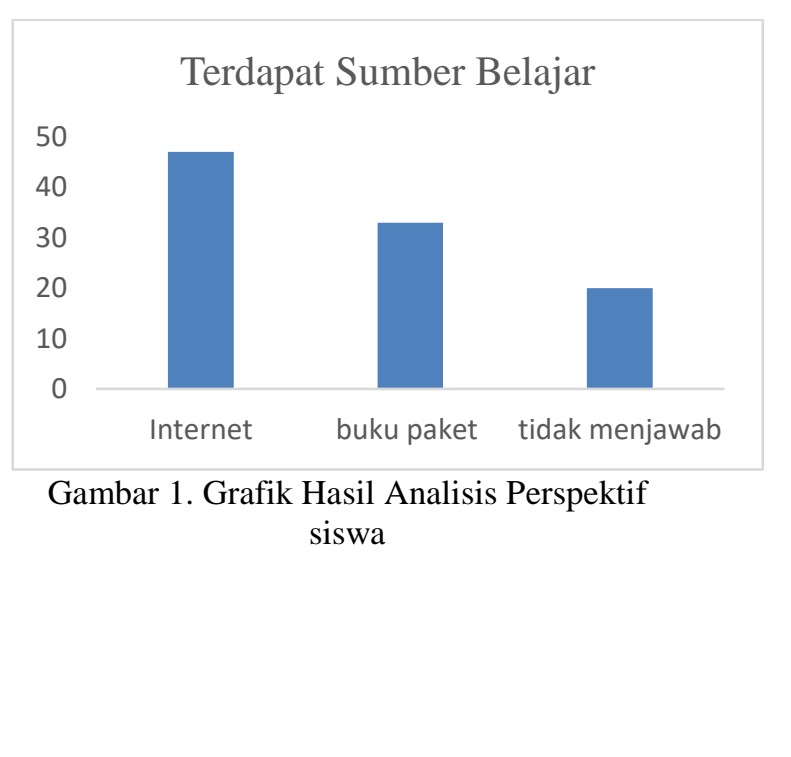




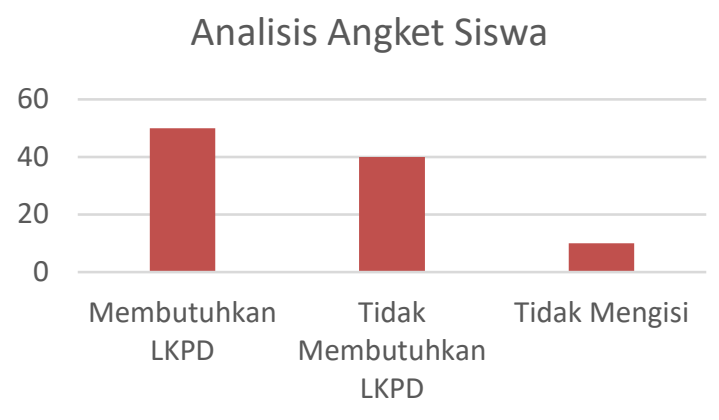

Gambar 2. Grafik Analisis Kebutuhan LKPD

\section{PEMBAHASAN}

Pada angket guru menyatakan materi yang sulit disampaikan adalah sel dan sistem peredaran darah. Pada angket siswa menuliskan bahwa materi sel sulit karena pada materi sel, siswa belum memahami dan mengerti mengenai oranel-organel sel masih ada kekeliruan. Sedangkan pada angket guru kesulitannya pada materi sel adalah mulai dari organel-organel sel, fungsi dari oragenl-organel sel serta perbedaan dari sel tersebut. Hal inilah membuat para siswa menjadi kurang paham dengan materi sel. Sejalan dengan penelitian Melati, (2006) bahwa mengenai Analisis Kesulitan Belajar Siswa Pada Materi Sel di Kelas XI SMA Negeri 1 Rasau Jaya, menyatakan bahwa jenis kesulitan yang dialami yaitu kesulitan konsep dan istilah, faktor penyebab kesulitan teridiri dari faktor internal dan eksternal.

Upaya yang dilakukan guru dalam menjelaskan materi sel pada pembelajaran daring adalah memberikan tugas. Sedangkan untuk hasil belajar siswa pada materi sel belum mencapai KKM (Kriteria Ketuntasan Minimum). Hal tersebut dikarenakan pada materi sel banyak siswa yang belum memahami konsep organel-organel sel, contohnya pada sel hewan. Bentuk penilaian pada proses pembelajaran daring yang digunakan guru adalah tes tertulis berupa soal-soal tentang materi sel. Dalam menentukan hasil penilaian hasil belajar biologi guru menilai tiga ranah, yaitu kognitif, afektif, dan psikomotor.

Beberapa kendala guru dalam menentukan hasil belajar siswa berdasarkan KKM (Kriteria Ketuntasan Minimum), meliputi daya dukung dan interaksi siswa, fasilitas yang tidak lengkap serta kurang mampu dalam mendukung proses pembelajaran siswa, kemudian kemampuan siswa yang beragam dan daya tangkap atau penguasaan mengenai materi pelajaran (Rahinosiwi, 2019). Menurut Setianingrum dan Sulistya (2016) Siswa yang masih memerlukan perbaikan karena belum mampu mencapai kriteria ketuntasan yang telah ditentukan dipengaruhi beberapa faktor yang datang dari luar dan dari dalam diri siswa.

Guru juga menginginkan perubahan pada proses pembelajaran materi sel, yaitu agar siswa tersebut bisa mengerti, memahami serta mengerjakan tugas yang diberikan agar hasilnya nanti akan bagus. Untuk itu, analisis kebutuhan bahan ajar dilakukan di SMAN 8 Palembang. Berdasarkan hasil Analisis Kebutuhan Lembar Angket Guru diperoleh bahwa guru membutuhkan LKPD berbasis model pembelajaran PBL pada materi sel. Hal ini sebagai solusi bagi guru pada pembelajaran daring untuk menggunakan LKPD yang terintegrasi langsung dengan sintaks PBL.

Berdasarkan pada Gambar 1 dan 2. Menunjukkan analisis hasil perspektif siswa terkait sumber belajar yang meliputi $47 \%$ penggunaan internet dan 33\% menggunakan buku paket. Rendahnya sumber belajar yang digunakan siswa sebagai penunjang pembelajaran dapat berpengaruh pada hasil belajar siswa. Hal ini sejalan dengan pernyataan guru bahwa nilai KKM untuk materi sel masih belum tuntas. Beberapa faktor penyebab diantaranya guru belum mengenal sintaks model pembelajaran, belum 
mengetahui LKPD yang terintegrasi model pembelajaran. Sehingga siswa juga mengharapkan adanya LKPD yang sebagai penunjang dalam pembelajaran daring. Hasil penyebaran angket juga menunjukkan sebanyak $50 \%$ siswa membutuhkan untuk dibuatkan LKPD materi sel.

\section{KESIMPULAN}

Berdasarkan hasil analisis kebutuhan pada guru biologi di SMA Negeri 8 Palembang menyatakan membutuhkan bahan ajar LKPD berbasis model PBL pada materi sel dan sebanyak $50 \%$ siswa menyatakan setuju untuk dibuatkan bahan ajar LKPD sebagai penunjang kegiatan pembelajaran daring.

\section{DAFTAR RUJUKAN}

Arends, I. R. 2008. Belajar Untuk Mengajar (Terjemahan Helly Prajitno Soehipto \& Sri Mulyatini Soetipto). New York: McGraw Hills.

Craig, C., \& Orland-Barak, L. 2015. International Teacher Education: Promising Pedagogies Introduction, Interntional Teacher Education: Promising Pedagogies (Part B( (Advances in Research on Teaching, Volume 22B). (pp. 1-5) Emeland Group Publishing Limited.

Ibrhim, I. 2013. Deskripsi Implementasi Kurikuluum 2013 Dalam Proses Pembelajaran Matematika di SMA Negeri 3 Maros Kabupten Maros. Daya Matematis: Jurnal Inovasi Pendidikan Matematika, 3(3): 370-378.

Melati, P. P. 2016. Analisis Kesulitan Belajar Siswa Pada Materi Sel Di Kelas XI SMA Negeri 1 Rasau jaya. Skripsi, Hal. 1-25.

Rahinosiwi, U. H. 2019. Analisis Hasil Belajar Siswa Berdasarkan KKM Dalam Pembelajan Tematik
Integratif Kelas IV Sekolah Dasar Negeri 02 Ploso Jumapolo. Skripsi. Surakarta. Universitas Muhammadiyah Surakarta.

Sari, Y. 2011. Analisis Faktor-faktor Yang Mmempengaruhi Keberhasilan Usaha Pedagang Kaki Lima di Galobo (Gladag Langen Bogan) Solo Thaun 2011. Skripsi. Surakarta. Universitas Negeri Surakarta.

Setianungrum, Sri, \& Sulistya, N. 2016. Upaya Peningkatan Hasil Belajar Tematik Melalui Discovery Learning Siswa Kelas 1 Sekolah Dasar. JPD (Jurnal Pendidikan Dasar), P-ISSN 2086-7433 EISSN 2549-5801.

Sulastri, I., \& Arif, F. 2014. Meningktkan Hasil Belajar Siswa Melalui Strategi Pembelajaran Berbasis Masalah Pada Materi Pelajaran IPS di Kelas V SDN 2 Limbu Makmur Kecamatan Bumi Jaya . Jurnal Kreatif Tadulako Online, 3(1)

Syabani, P., \& Damawati. 2018. Deveploment Of Students Worksheet Based On Material Changes And Conservation Of Living Environment For Lerning Biology Tenth Grade Senior High School . Jurnal Online Mahasiswa, 5(1).

Widyantini, T. 2013. Penyusun Lembar Kegiatan Siswa (LKS) sebagai bahan ajar. Pusat Pengembangan dan Pemberdayaan Pendidik dan Tenaga Kependidikan (PPPPTK) Matematika , Yogyakarta: PPPPTK Matematika.

Wulandari, B., \& Surjono, H. D. 2013. Pengaruh Problem Based Learning Terhadap Hasil Belajar Ditinjau Dari Motivasi Belajar PLC di SMK. Jurnal Pendidikan Vokasi, 3(2): 1-10. 